\title{
As transformações do telejornalismo brasileiro e suas implicações no telejornal regional: um estudo de Paraná TV $1^{\mathrm{a}}$ edição
}

\author{
Autor:Ana Carolina Felipe Contato \\ Orientador: Florentina das Neves Souza
}

Resumo: Este trabalho faz uma retomada dos principais momentos do telejornalismo no Brasil, expõe os diferentes formatos telejornalísticos e eleje o telejornal diário regional como objeto de análise. Observando as transformações dos telejornais em relação ao formato e linguagem desde os anos 1950 até a atualidade, busca-se por meio de estudo bibliográfico, entrevistas e exame de telejornais das décadas de 1980, 1990 e 2000 verificar quais foram as principais mudanças. São selecionados itens de linguagem verbal, visual e de conteúdo do telejornal local Paraná TV, da emissora TV Coroados, afiliada à Rede Globo em Londrina.

Palavras-chave: Telejornalismo. Brasil, Telejornalismo. Londrina (PR). Comunicação de massa. Comunicação social. 


\title{
The transformations of Brazillian television news and its implications on local daily newscast: a study of Paraná TV $1^{a}$ Edição
}

\begin{abstract}
This work summarizes the most important moments of Brazilian $T V$ news, exposes the different kinds of telejournalism and elects regional daily newscast as object of analysis. It aims at verifying what kind of changes ocurred, observing the transformations in language and format since the 1950's until nowadays, by means of studing the literature, interviewing people who made and still make TV news and scanning daily newscasts from the 1980 's, 1990's and 2000's. Verbal, visual and content itens are selected from the TV news Paraná TV, from TV Coroados, affiliated of Rede Globo in the city of Londrina.
\end{abstract}

Keywords: Television journalism, Brazil, Television journalism, Londrina $(P R)$, Mass communication

Dissertação completa disponível em: http://www.bibliotecadigital.uel.br/ document/?view $=$ vtls000189629 